\title{
ASPEK HUKUM PENCANTUMAN IDENTITAS PASFOTO KEPEMILIKAN HAK ATAS TANAH DALAM SERTIFIKAT DITINJAU DARI PERATURAN PEMERINTAH NO 24 TAHUN 1997
}

\author{
Samuel Soewita \\ Fakultas Hukum, Universitas Pamulang \\ Email :sam.soewita@gmail.com
}

Received: - /Revised: - /Accepted: Ags 2018

\begin{abstract}
"ASPEK HUKUM PENCANTUMAN IDENTITAS PASFOTO KEPEMILIKAN HAK ATAS TANAH DALAM SERTIFIKAT DITINJAU DARI PERATURAN PEMERINTAH NO 24 TAHUN 1997". Dalam rangka pembangunan nasional yang berkesinambungan, peranan tanah akan menjadi bertambah penting sehubungan dengan terus bertambahnya jumlah penduduk yang semuanya memerlukan tanah untuk pemukiman, dan dengan semakin meningkatnya jumlah pembangunan, kebutuhan tanah untuk diusahakan seperti lahan perumahan, pertanian dan industri juga akan meningkat, seiring dengan hal tersebut akan meningkat pula kebutuhan dukungan jaminan atau kepastian hukum di bidang pertanahan. Tujuan utama dari penelitian ini adalah untuk mengetahui dan menganalisa tentang diperlukannya pencantuman pasfoto pemilik hak atas tanah dalam sertifikat diperlukan ditinjau dari PP No 24 / 1997 tentang Pendaftaran Tanah. Dengan diselenggarakan pendaftaran tanah, maka mereka yang memiliki hak atas tanah akan dapat membuktikan haknya atas tanah yang dikuasai dan dimilikinya tersebut dengan adanya foto dari pemilik. Pencantuman foto sebagai identitas yang pasti akan pemilik yang sah dari sebuah sertifikat khususnya untuk perorangan sangat efektif dan tidak dapat tertukar yang pemilik yang namanya sama tetapi fotonya berbeda. Metode penelitian yang digunakan adalah Yuridis Sosiologis, dengan menggunakan Data Primer dan Data Sekunder, dengan analisis secara deskripsi kualitatif.
\end{abstract}

Kata kunci : pencantuman foto pada sertifikat. 


\begin{abstract}
"LEGAL ASPECT OF IDENTITY PASFOTO IDENTIFICATION OF THE RIGHT TO LAND OF SERIFICATED CERTIFICATE OF GOVERNMENT REGULATION NO. 24 YEAR 1997". Within the framework of sustainable national development, entities will be of paramount importance with the ever-increasing population of all land, and with more development, the need for cultivated land such as housing, agriculture and industry will also increase, as it will increase also costs or legal certainty in the land sector. The main purpose of this research is to know and analyze the necessity of inclusion of photograph of the owner of land right in the required certificate in view of PP No 24/1997 about Land Registration. With the holding of the land, then those who have the right to land will be able to change their rights to the land that is occupied and staged with a photo of the owner. The inclusion of a photo as a definite identity of the rightful owner of a special certificate for an individual is very effective and can not be used by another owner. The research method used is Juridical Sociology, using Primary Data and Secondary Data, with qualitative analysis. In the certificate creation process, there is still an error in the identity certificate.
\end{abstract}

Keywords : the photograph contained in the certificate.

\title{
PENDAHULUAN
}

Dalam rangka pembangunan nasional yang berkesinambungan, peranan tanah akan menjadi bertambah penting sehubungan dengan terus bertambahnya jumlah penduduk, yang semuanya memerlukan tanah untuk pemukiman, dan dengan semakin meningkatnya kegiatan pembangunan, kebutuhan akan tanah untuk diusahakan juga akan meningkat, seiring dengan itu akan meningkat pula kebutuhan akan dukungan berupa jaminan kepastian hukum di bidang pertanahan.

Pemberian jaminan kepastian hukum dibidang pertanahan memerlukan tersedianya : Pertama, perangkat hukum tertulis yang lengkap dan jelas serta dilaksanakan secara konsisten. Kedua, penyelenggaraan pendaftaran tanah yang efektif. 
Dengan tersedianya perangkat hukum tertulis, siapapun yang berkepentingan akan dapat dengan mudah mengetahui segala sesuatu yang berkaitan dengan penguasaan dan penggunaan tanah. Bilamana seorang membutuhkan tanah, dari ketentuan hukum yang berlaku akan diketahui cara memperolehnya dan apa yang akan menjadi alat buktinya, tetapi bagi mereka yang akan membeli hak atas tanah atau bagi calon kreditur yang akan menerima suatu hak atas tanah sebagai jaminan pengetahuan akan hal tersebut, bagaimanapun pentingnya, belum cukup untuk sampai pada keputusan untuk membeli tanah yang ditawarkan kepadanya ataupun untuk menerima tanah yang akan diserahkan kepadanya sebagai jaminan. Ia ingin memperoleh kepastian terlebih dahulu tanah yang akan dibelinya atau tanah yang akan dijaminkan kepadanya itu tanah yang mana, letaknya dimana, bagaimana batas-batasnya, berapa luasnya, juga tidak kalah penting siapa pemegang haknya dan ada atau tidak adanya hak pihak lain. Semua itu diperlukan untuk mengamankan perbuatan hukum yang akan dilakukannya dan mencegah timbulnya sengketa di kemudian hari.

Keterangan yang dimaksudkan tidak mungkin diperoleh dari perundang-undangan yang tersedia. Untuk itu diperlukan penyekenggaraan kegiatan pendaftaran tanah. Dengan diselenggarakan pendaftaran tanah, maka mereka yang memiliki hak atas tanah akan dapat membuktikan haknya atas tanah yang dikuasai dan dimilikinya tersebut dengan adanya foto dari pemilik. Pencantuman foto sebagai identitas yang pasti akan pemilik yang sah dari sebuah sertifikat khususnya untuk perorangan sangat efektif dan tidak dapat tertukar yang pemilik yang namanya sama tetapi fotonya berbeda. 
Dengan kata lain, pencantuman pasfoto memberi jaminan kepastian hukum bidang pertanahan, pertama-tama memerlukan tersedianya perangkat hukum tertulis, lengkap dan jelas yang dilaksanakan secara konsisten sesuai dengan jiwa dan isi ketentuan-ketentuannya. Selain itu dalam menghadapi kasuskasus konkret diperlukan juga terselenggaranya pendaftaran tanah yang memungkinkan bagi pemegang hak atas tanah untuk dengan mudah membuktikan hak atas tanah yang dimiliki atau dikuasainya, bagi para pihak yang berkepentingan, seperti calon pembeli dan calon kreditur, untuk memperoleh keterangan yang diperlukan mengenai tanah yang menjadi obyek perbuatan hukum yang akan dilakukan, serta bagi pemerintah untuk melaksanakan kebijakan pertanahan.

Undang-Undang nomor 5 Tahun 1960 tentang Peraturan Dasar Pokok-pokok Agraria, dalam ketentuan Pasal 19 memerintahkan diselenggarakannya pendaftaran tanah guna menjamin kepastian hukum tersebut, yang berbunyi sebagai berikut:

1. Untuk menjamin kepastian hukum oleh Pemerintah diadakan pendaftaran tanah di seluruh wilayah Republik Indonesia menurut ketentuan-ketentuan yang diatur dengan Peraturan Pemerintah.

2. Pendaftaran tersebut dalam ayat (1) pasal ini meliputi :

a. Pengukuran, perpetaan dan pembukuan tanah:

b. Pendaftaran hak-hak atas tanah dan peralihan hak-hak tersebut,

3. Pemberian surat-surat tanda bukti hak, yang berlaku sebagai alat pembuktian yang kuat 
4. Pendaftaran tanah diselenggarakan dengan mengingat keadaan Negara dan masyarakat, keperluan lalu lintas social ekonomis serta kemungkinan penyelenggaraannya, menurut pertimbangan Menteri Agraria.Dalam Peraturan Pemerintah diatur biaya-biaya yang bersangkutan dengan pendaftaran termaksud dalam ayat (1) di atas, dengan ketentuan bahwa rakyat yang tidak mampu dibebaskan dari pembayaran biaya-biaya tersebut.

Berdasarkan apa yang diperintahkan ayat (1) Pasal 19 tersebut, maka oleh Pemerintah telah diterbitkan Peraturan Pemerintah Nomor 10 Tahun 1961. Untuk pertama kalinya kegiatan pendaftaran tanah di seluruh Indonesia diselenggarakan berdasarkan peraturan pemerintah tersebut. Namun dalam kenyataannya pelaksanaan kegiatan pendaftaran tanah tersebut selama lebih dari 53 tahun belum memberikan hasil sebagaimana yang diharapkan, sehingga ketentuan tersebut dianggap belum cukup memberikan hasil untuk melaksanakan pendaftaran tanah dalam waktu singkat dan dengan hasil yang memuaskan.

Sehubungan dengan itu maka dalam rangka meningkatkan dukungan yang lebih kuat dan mantap kepada para pelaku pembangunan serta disisi lain untuk melindungi kepentingan nasional dalam menghadapi arus globalisasi yang sudah mulai dirasakan dewasa ini, perlu ditingkatkan kepastian hokum di bidang pertanahan, untuk itu pemerintahan mengadakan penyempurnaan pada peraturan pendaftaran tanah dengan menerbitkan Peraturan Pemerintah Nomor 24 Tahun 1997.

Dari apa yang telah dikemukakan di atas, penulis merasa perlu mengadakan penelitian dan pengkajian tentang pendaftaran 
tanah menurut Peraturan Pemerintah No 10 Tahun 1961 dan Peraturan Pemerintah Nomor 24 Tahun 1997.

\section{PERMASALAHAN}

1. Apakah pencantuman identitas pasphoto pemilik hak atas tanah dalam sertifikat diperlukan?

2. Apakah pencantuman identitas pasphoto dalam sertifikat dapat meminimalkan pemalsuan data kepemilikan hak atas tanah?

\section{METODE PENELITIAN}

a. Jenis Penelitian

Metode dalam penelitian ini adalah :

1) Penelitian Hukum Normatif Penelitian Hukum Normatif meliputi penelitian terhadap asas-asas hukum, sistematika hukum, sinkronisasi hukum secara vertical dan horizontal agar terjadi keserasian peraturan per undang-undang an tersebut berdaasarkan hirarki per undang-undangan agar tidak bertentangan satu sama lain, perbandingan hukum.

2) Penelitian Empiris atau Sosiologis, Penelitian terhadap efektivitas, suatu per undang-undangan dengan penerapan pada masyarakat.

b. Spesifikasi Penelitian

Spesifikasi penelitian ini menggunakan deskriptif analisis, yaitu berupa pemaparan secara terinci dan terukur yang dapat di analisis dengan suatu norma hukum yang berlaku.

c. Jenis dan Sumber Data

Jenis data yang digunakan adalah Data Sekunder (data dari bahan pustaka), mencakup dokumen-dokumen resmi, bukubuku, hasil penelitian berujud laporan, buku harian dan lain-lain.

Jenis-jenis data sekunder terdiri dari

1) Data Pribadi (dokumen pribadi)

2) Data Hukum

a) Bahan Hukum Primer ( yaitu bahan-bahan yang mengikat, yang terdiri dari Pancasila, UUD 1945, Ketetapan MPR, UU/Perpu, PP, Perpres atau Keppres, Perda) $\backslash$

b) Bahan Hukum Sekunder ( yaitu bahan-bahan 
yang memberikan penjelasan mengenai bahan hukukm primer, seperti RUU, hasil karya ilmiah dari kalangan hukum dan lain-lain)

c) Bahan hukum tersier ( yaitu bahan yang memberikan petunjuk maupun penjelasan terhadap bahan hukum primer dan bahan hukum sekunder, seperti kamus, ensiklopedi, indeks kumulatif dan lain-lain)

\section{PEMBAHASAN}

Diperoleh gambaran bahwa faktor-faktor yang mengakibatkan terhambatnya pelaksanaan pendaftaran tanah disebabkan oleh beberapa faktor yaitu:

a) Adanya kesalahan informasi yang diberikan oleh pihak pemohon.

Kesalahan informasi yang diberikan oleh pemohon disebabkan kurang proaktifnya masyarakat sebagai pemohon untuk datang langsung ke kantor pertanahan menanyakan hal-hal apa saja yang menjadi persyaratan administrasi yang harus disiapkan dalam proses awal pendaftaran tanah, sehingga kebanyakan dari masyarakat yang datang untuk melakukan pendaftaran tanahnya syarat-syarat administrasinya yang harus dipenuhi tidak lengkap sehingga dikembalikan berkasnya dan tidak diproses lebih lanjut oleh panitia bagian pemeriksaan berkas. Kesalahan informasi awal yang diberikan juga kadangkala terjadi dari pihak kantor pertanahan, hal ini terjadi akibat kurangnya sosialisasi kemasyarakat dengan penyuluhan-penyuluhan yang dilakukan di masyarakat sehingga informasi yang didapat oleh pemohon kurang yang berakibat pada saat pemohon mendaftarkan tanahnya, berkas administrasi yang diserahkan oleh pemohon tidak lengkap. Hal 
ini menjadi dasar dari informasi yang kurang lengkap diberikan oleh pihak kantor pertanahan.

b) Adanya sanggahan/keberatan dari pihak lain pada saat proses pendaftaran tanah berlangsung. Sanggahan/keberatan dari pihak lain disebabkan karena tanah yang didaftarkan pemohon adalah tanah sengketa sehingga pada saat prosesnya tanah tersebut tidak dilanjutkan oleh panitia yang melakukan pengukuran dan pemetaannya dikembalikan terlebih dahulu kepada pemohon untuk menyelesaikan sengketa tanah tersebut dan apabila sengketa permasalahan tanah tersebut telah selesai maka panitia akan melanjutkan kembali pengukuran dan pemetaan yang pernah dilakukannya. Namun, kadangkala yang terjadi apabila sengketa hak atas tanah telah diselesaikan oleh pihak pemohon maka yang seharusnya adalah dilanjutkan prosedur pendaftarannya. Akan tetapi pemohon harus mendaftarkan kembali lagi dari tahap awal pendaftaran tanah.

c) Adanya faktor kesadaran hukum Pada prinsipnya faktor kesadaran hukum merupakan salah satu indikator yang cukup efektif mempengaruhi pelaksanaan pendaftaran tanah di kota Depok, karena faktor kesadaran hukum itu sendiri senantiasa terkait dengan perilaku, ketaatan dan kepatuhan seseorang (pemilik tanah dan aparat kantor pertanahan kota Depok) untuk melakasanakan pendaftaran tanah sesuai ketentuan hukum yang diatur dalam PP Nomor 24 Tahun 1997 juncto UU Nomor 5 Tahun 1960. Dikatakan bahwa faktor kesadaran hukum sebagai salah satu indikator penentu terhadap keberhasilan pelaksanaan pendaftaran tanah, karena secara faktual faktor kesadaran hukum senantiasa bertalian 
dengan kepribadian seseorang yang menguasai atau memiliki bidang - bidang tanah tertentu, maupun terhadap aparat kantor pertanahan kota Depok yang bertugas dan berkewajiban melaksanakan pendaftaran tanah. Sehingga sebagian besar responden beranggapan bahwa faktor kesadaran hukum bertalian nilai - nilai sosial dan kemasyarakatan yang tidak dapat dipisahkan dari prinsip prinsip dasar pelaksanaan pendaftaran tanah sebagaimana dimaksud dalam pasal 2 PP Nomor 24 Tahun 1997. Norma atau kaidah hukum yang harus ditegakkan dalam rangka pelaksanaan mungkin agar tujuan pendaftaran tanah dapat diwujudkan. Bahwa berdasarkan pengamatan penulis, kesadaran hukum masyarakat untuk mendaftarakan tanahnya cukup tinggi, karena melalui pendaftaran tanah pemerintah akan memeberikan perlindungan dan kepasrtian hukum terhadap bidang tanah yang telah didaftarakan. Apabila tanah yang dimohonkan untuk didaftarkan sudah dilakukan pendaftaran, maka kantor pertanahan kota Depok akan memberikan sertifikat hak atas tanah. Sedangkan tanah yang sudah bersertifikat lebih aman daripada tanah yang belum bersertifikat. Sekalipun tingkat kesadaran hukum pemilik tanah dan aparat kantor pertanahan kota Depok, dikatakan cukup efektif mempengaruhi pelaksanaan pendaftaran tanah. Namun patut diakui bahwa kesadaran hukum itu, harus didukung dengan tingkat kemampuan ekonomi masyarakat untuk membayar segala biaya yang dibutuhkan dalam rangka pelaksanaan pandaftaran tanah.

d) Pemohon menggunakan jasa orang lain. Pemohon menggunakan jasa orang lain (calo) disebabkan karena 
pemohon tidak mau susah dalam hal pengurusan administrasinya sehingga mereka menggunakan jasa orang lain, ini dikarenakan pemohon hanya menginkan kemudahannya saja tanpa harus bolak balik ke kantor pertanahan untuk mendaftarkan tanahnya. Penggunaan jasa orang lain diakibatkan oleh berbelit-belitnya prosedur administrasi pada pandaftaran yang menyebabkan pemohon ingin segera menyelesaiakan proses dengan menggunakan jasa calo. Penggunaan jasa calo juga menimbulkan konsekuensi seperti adanya biaya di luar biaya pendaftaran.

e) Adanya faktor ekonomi atau biaya pendaftaran tanah Faktor ekonomi sebagai salah satu indikator yang berpengaruh terhadap pelaksanaan tanah di kota Depok, berorientasi pada kemampuan pemilik tanah untuk membiayai segala perongkosan yang dibutuhkan dalam rangka pelaksanaan pendaftaran tanah. Walaupun masyarakat mempunyai kemampuan ekonomi untuk membiayai bidang-bidang tanah yang akan didaftarkan, kalau yang bersangkutan tidak mempunyai tanah maka pendaftaran tanah tidak dapat dilakukan. Kantor pertanahan kota Depok hanya mendaftar bidang-bidang tanah yang mempunyai kelengkapan data fisik dan data yuridis, apabika data fisik dan data yiridis tidak mendukung maka tanah yang dimohonkan untuk didaftar tidak akan didaftarkan. Walaupun yang bersangkutan mempunyai kesanggupan membayar keseluruhan biaya yang diperlukan dalam rangka pelaksanaan pendaftaran tanah, maka permohonan pendaftaran tanah yang bersangkutan akan ditolak. Sehubungan dengan hal tersebut, faktor ekonomi dalam arti kemampuan membayar biaya pendaftaran tanah 
senantiasa bertalian dengan ketersediaan bidang tanah yang akan didaftarkan, bidang-bidang tanah yang di mohonkan pendaftarannya, harus di dukung dengan kelengkapan data fisik dan data yuridis. Dengan demikian, maka sekalipun pemohon mampu membayar biaya pendaftaran tanah kalau yang bersangkutan tidak memiliki tanah yang akan didaftarkan tidak akan mempengaruhi aparat kantor pertanahan kota Depok untuk melakukan pendaftaran tanah. Pendaftaran tanah dilakukan apabila bidang tanah yang dimohonkan, didukung dengan data fisik dan data yuridis yang cukup lengkap. Menurut keterangan Ny. Mely selaku pemohon pendaftaran tanah untuk dibalik nama di kota Depok (wawancara, jumat 10 April 2015) mengemukakan, bahwa pelaksanaan pendaftaran tanah biayanya tidak terlalu besar dan dapat dijangkau oleh masyarakat. Lain halnya kalau pendaftaran tanpa melalui proyek prona, maka biaya pendaftaran tanah relatif lebih besar. Minimnya biaya yang diperlukan dalam rangka pendaftaran tanah melalui proyek prona, karena adanya subsidi dari pemerintah melalui Anggaran Pendapatan dan Belanja Negara.

\section{Faktor-Faktor penyebab pemalsuan Sertifikat Tanah.}

Adapun beberapa kasus yang pernah penulis temukan dalam proses pemalsuan sertifikat antara lain :

a. Pemalsuan KTP dari pemilik asli yang sudah meninggal, di palsukan dengan cara ada figur yang seolah-olah menjadi pemilik KTP yang sah, lalu melakukan pengajuan proses pembuatan sertifikat tanah yang berasal dari tanah adat. KTP (Asli tapi palsu) dijadikan dasar dalam pembuatan 
sertifikat, biasanya hal ini terjadi dalam kasus perebutan warisan dari beberapa ahli waris. Pelaku yang memalsukan KTP dengan cara di figur tersebut membuat Akte Hibah kepada pelaku, sehingga tanah tersebut telah dihibahkan oleh pewaris kepada pelaku tersebut sewaktu pewaris masih hidup.

b. Pemalsuan dari Riwayat Tanah oleh oknum Kelurahan dan Kecamatan, dimana riwayat tanah dari Letter C, di ubah kepemilikannya seolah-olah milik $\mathrm{Tn} \mathrm{X}$, yang mana sebenarnya tanah di Letter $\mathrm{C}$ baik di Kelurahan dan Kecamatan adalah milik Tn Y.. Pada umumnya tanah tersebut yang tidak pernah di urus oleh ahli warisnya, atau ahli warisnya tidak di ketahui keberadaannya.

c. Pemalsuan Akte Jual Beli, dalam hal pemalsuan ini, pemilik asli dari sebuah sertifikan yang sedang membutuhkan uang dan meminjam terhadap mafia. Modus yang dilakukan adalah melakukan tanda tangan pada blanko kosong dengan alasan untuk latihan tanda tangan pada saat akad kredit, dan pemilik sertifikat diberikan sejumlah uang yang lagi dibutuhkan seolah-olah telah mendapat pinjaman, namun tanda tangan di blanko kosong tersebut kemudian di cetak menjadi akte jual beli melalui perantaraan oknum notaris, dan seolah-olah terjadi jual beli. Setelah berganti pemilik, Sertifikat tersebut di agunkan pada sebuah bank dan tidak pernah di cicil, sehingga aset tanah tersebut di sita oleh Bank. Sedangkan pemilik tidak pernah menandatangani perjanjian kredit, tetapi pihak bank berusaha untuk melakukan upaya hukum sita jaminan. 


\section{Pencantuman Pasphoto Dalam Sertifikat diperlukan.}

a. Pada saat pertama kali pendaftaran tanah

Pada saat pertama kali pendaftaran tanah adalah untuk melakukan suatu permohonan pembuatan sertifikat asal dari tanah milik adat (konversi / pengakuan hak) memerlukan beberapa lampiran yang dibutuhkan yaitu :

- Permohonan Sertifikat (Lampiran 13) Rangkap tiga

- Surat Pernyataan Penguasaan Fisik bidang Tanah Sporadik (lampiran 14)

- Surat Keterangan Riwayat Tanah

- Girik / Foto copy C. Induk Desa An. Penjual dan asal usul tanah Tanggal 24-09-1960 (dilegalisir)

- Lunas PBB tahun terakhir

- Foto Copy KTP Pemohon atau Bukti Subyek (Legalisir)

- Akta atau Bukti-bukti peralihan yang berhubungan dengan obyeknya.

- NO. Gambar Situasi / Surat Ukur

- Surat Kuasa untuk mengurus dan foto copy KTP Penerima Kuasa

b. Pada saat jual beli dan balik nama sertifikat

Dalam proses balik nama sertifikat tanah, dibutuhkan data sebagai berikut :

Data tanah, meliputi:

a) Asli PBB 5 tahun terakhir berikut Surat Tanda Terima Setoran (bukti bayarnya).

b) Asli sertifikat tanah (untuk pengecekan dan balik nama).

c) Asli IMB (bila ada, dan untuk diserahkan pada Pembeli setelah selesai proses AJB). 
d) Bukti pembayaran rekening listrik, telpon, air (bila ada).

e) Jika masih dibebani Hak Tanggungan (Hipotik), harus ada Surat Roya dari Bank yang bersangkutan.

Catatan: point a \& b mutlak harus ada, tapi yang selanjutnya optional

Data Penjual \& Pembeli (masing-masing) dengan kriteria sebagai berikut:

1. a).Perorangan: Copy KTP suami isteri. Copy Kartu keluarga dan Akta Nikah. Copy Keterangan WNI atau ganti nama (bila ada, untuk WNI keturunan).

2. Perusahaan: Copy KTP Direksi \& komisaris yang mewakili. Copy Anggaran dasar lengkap berikut pengesahannya dari Menteri Hukum dan HAM RI. Rapat Umum Pemegang Saham PT untuk menjual atau Surat Pernyataan Sebagian kecil asset. Catatan: Untuk fotokopi identitas diri, Akta Nikah dan Kartu Keluarga, wajib dibawa dan diperlihatkan aslinya kepada notaris pada saat penandatanganan.

Dalam hal Suami/isteri atau kedua-duanya yang namanya tercantum dalam sertifikat sudah meninggal dunia, maka yang melakukan jual beli tersebut adalah Ahli Warisnya. Jadi, data-data yang diperlukan adalah:

Surat Keterangan Waris Untuk pribumi: Surat Keterangan waris yang disaksikan dan dibenarkan oleh Lurah yang dikuatkan oleh Camat. Untuk WNI keturunan: Surat keterangan Waris dari Notaris

Copy KTP seluruh ahli waris. Copy Kartu keluarga dan Akta Nikah Seluruh ahli waris harus hadir untuk tanda-tangan AJB, atau Surat Persetujuan dan kuasa dari seluruh ahli waris kepada salah seorang di antara mereka yang dilegalisir oleh Notaris 
(dalam hal tidak bisa hadir). bukti pembayaran BPHTB Waris (Pajak Ahli Waris), dimana besarnya adalah 50\% dari BPHTB jual beli setelah dikurangi dengan Nilai tidak kena pajaknya. Berdasarkan hasil penelitian dan data yang diperoleh baik yang berasal dari Kantor Badan Pertanahan Nasional atau yang bersumber dari praktek jual beli pada kantor Notaris, ditemukan bahwa tidak ada peraturan pelaksanaan atau peraturan teknis bahwa pencantuman pasphoto dalam sertifikat diperlukan sebagai data yang otentik tentang pemilik yang sah untuk sebidang tanah yang dikuasai atau dimiliki.

Pencantuman Pasphoto dalam Sertifikat dapat meminimalkan pemalsuan data kepemilikan sertifikat.

Adapun beberapa kasus yang pernah penulis temukan dalam proses pemalsuan sertifikat antara lain :

1) Pemalsuan KTP dari pemilik asli yang sudah meninggal, di palsukan dengan cara ada figur yang seolah-olah menjadi pemilik KTP yang sah, lalu melakukan pengajuan proses pembuatan sertifikat tanah yang berasal dari tanah adat. KTP (Asli tapi palsu) dijadikan dasar dalam pembuatan sertifikat, biasanya hal ini terjadi dalam kasus perebutan warisan dari beberapa ahli waris. Pelaku yang memalsukan KTP dengan cara di figur tersebut membuat Akte Hibah kepada pelaku, sehingga tanah tersebut telah dihibahkan oleh pewaris kepada pelaku tersebut sewaktu pewaris masih hidup.

2) Pemalsuan dari Riwayat Tanah oleh oknum Kelurahan dan Kecamatan, dimana riwayat tanah dari Letter C, di ubah kepemilikannya seolah-olah milik Tn X, yang mana 
sebenarnya tanah di Letter C baik di Kelurahan dan Kecamatan adalah milik Tn Y.. Pada umumnya tanah tersebut yang tidak pernah di urus oleh ahli warisnya, atau ahli warisnya tidak di ketahui keberadaannya.

3) Pemalsuan Akte Jual Beli, dalam hal pemalsuan ini, pemilik asli dari sebuah sertifikan yang sedang membutuhkan uang dan meminjam terhadap mafia. Modus yang dilakukan adalah melakukan tanda tangan pada blanko kosong dengan alasan untuk latihan tanda tangan pada saat akad kredit, dan pemilik sertifikat diberikan sejumlah uang yang lagi dibutuhkan seolah-olah telah mendapat pinjaman, namun tanda tangan di blanko kosong tersebut kemudian di cetak menjadi akte jual beli melalui perantaraan oknum notaris, dan seolah-olah terjadi jual beli. Setelah berganti pemilik, Sertifikat tersebut di agunkan pada sebuah bank dan tidak pernah di cicil, sehingga aset tanah tersebut di sita oleh Bank. Sedangkan pemilik tidak pernah menandatangani perjanjian kredit, tetapi pihak bank berusaha untuk melakukan upaya hukum sita jaminan. Berdasarkan data yang diperoleh penulis, bahwa tidak adanya pasphoto dalam sebuah sertifikat sangat mudah di palsukan oleh oknum-oknum yang tidak bertanggungjawab.

\section{KESIMPULAN}

1. Adanya Identitas Pasphoto Dari Pemilik Dalam Sertifikat Sangat Diperlukan Agar Dapat Membedakan Antara Pemilik Yang Satu Dengan Pemilik Lainnya Yang Kemungkinan Namanya Sama. 
2. Adanya Pasphoto Di Sertifikat Tanah Yang Merupakan Tanda Bukti Pemilikan Tanah Yang Bernilai Jutaan Rupiah Bahkan Sampai Miliaran Rupiah Harus Menjamin Pemilik, Bahwa Tanah Yang Dimiliki Sesuai Dengan Sertifikat Adalah Sah Secara Hukum Dan Dapat Meminimalkan Pemalsuan Sertifikat

\section{SARAN}

1. Agar pihak Kantor Pertanahan dalam melakukan proses pendaftaran tanah, senantiasa memperhatikan kelengkapan informasi dan data yang diberikan pemohon dalam hal ini identitas pasphoto dari pemilik atau calon pemilik sertifikat tanah.

2. Perlu ada aturan setingkat Menteri yang mengatur tentang pencantuman pasphoto pemilik dalam sebuah sertifikat kepemilikan tanah sehingga memberi jaminan kepastian hukum dalam memiliki sebuah bidang tanah, seperti sebuah Ijazah atau Pasport ada identitas pasphoto pemilik, sehingga pemalsuan sertifikat oleh oknum-oknum tertentu dapat dihindarkan bahkan diminimalkan.

\section{DAFTAR PUSTAKA}

\section{BUKU}

Abdurrahman, "Beberapa Aspekta Tentang Hukum Agraria”, Seri Hukum Agraria V, Alumni, Bandung, 1980.

Achmad Ali, "Mengembara Di Belantara Hukum", Lembaga Penerbitan Universitas Hasanuddin, Ujung Pandang, 1993.

Achmad Ali, "Menguak Tabir Hukum Sebuah Kajian Filosofis dan Sosiologis", Cetakan Kedua, PT. Toko Gunung Agung Tbk, Jakarta, 2002.

Adami Chazawi, "Pelajaran Hukum Pidana 1", Cetakan 2, PT. RajaGrafindo Persada, Jakarta, 2005. 
Adami Chazawi, "Pelajaran Hukum Pidana 2", PT. RajaGrafindo Persada, Jakarta, 2002.

Adami Chazawi, “Pelajaran Hukum Pidana 3”, PT. RajaGrafindo Persada, Jakarta, 2011.

Adami Chazawi, "Kejahatan Terhadap Pemalsuan", PT. RajaGrafindo Persada, Jakarta, 2001.

Amir Ilyas, "Asas-Asas Hukum Pidana", Rangkang Education dan PuKap, Yogyakarta, 2012.

Andi Hamzah, "Delik-Delik Tertentu (Speciale Delicten) Di Dalam KUHP”, Sinar Grafika, Jakarta, 2009.

Andi Zainal Abidin Farid, "Hukum Pidana I", Cetakan Kedua, Sinar Grafika. Jakarta, 2007.

Andi Zainal Abidin Farid, "Asas-Asas Hukum Pidana 1", Alumni. Bandung, 1987.

A.P. Perlindungan I, "Pendaftaran Tanah Di Indonesia", Mandar Maju, cetakan 2 Bandung, 1999.

A.P. Perlindungan I, "Pendaftaran Tanah Di Indonesia", Mandar Maju, Bandung, 1990.

Boedi Harsono I, "Hukum Agraria Indonesia Sejarah Pembentukan Undang - Undang Pokok Agraria, Isi, Dan Pelaksanaanya”. Djambatan, Jakarta, 2003.

Boedi Harsono I, "Hukum Agraria Indonesia; Himpunan Peraturan - Peraturan Hukum Tanah”, Jakarta, Djambatan. 1993.

C.G Van Huls, "Trijdscrift Voor Het Kadaster In NederlandschIndie", Batavia, 1937.

Dr. Urip Santoso, "Pendaftaran Dan Peralihan Hak Atas Tanah", Kencana, Jakarta, 2011.

Effendi Bachtiar, "Kumpulan tulisan tentang hukum tanah", Alumi, Bandung, 1993. 
Ilham Gunawan, “Kamus Hukum”, CV. Restu Agung, Jakarta, 2002.

Irwan Soerodjad, "Kepastian Hukum Hak Atas Tanah Di Indonesia”, Arkola, Surabaya, 2002.

John Salindeho, "Masalah Tanah Dalam Pembangunan", Sinar Grafika, Jakarta, 1993.

Leden Marpaung, “Asas-Teori-Praktik Hukum Pidana”, Cetakan Keenam. Sinar Grafika. Jakarta, 2009.

Leden Marpaung, "Proses Penanganan Perkara Pidana (Penyelidikan \& Penyidikan)", Cetakan ketiga, Sinar Grafika. Jakarta, 2011.

Mhd Yamin Lubis dan Abd. Rahim Lubis, "Hukum Pendaftaran Tanah”, Mandar Maju, Bandung, 2008.

P.A.F Lamintang, "Dasar-Dasar Hukum Pidana Indonesia”, PT. Citra Adikarya Bakti, Bandung, 1997.

P.A.F Lamintang, "Delik-Delik Khusus: Kejahatan Membahayakan Kepercayaan Umum Terhadap Surat, Alat Pembayaran, Alat Bukti dan Peradilan”, Sinar Grafika. Jakarta, 2009.

Rusli Effendy, "Azas-Azas Hukum Pidana”, Lembaga Percetakan dan Penerbitan Universitas Muslim Indonesia, Ujung Pandang, 1986.

R. Soesilo, "Kitab Undang-Undang Hukum Pidana (serta komentar-komentar Pasal demi Pasal)”, Politea, Bogor, 1996.

Satjipto Rahardjo, "Ilmu Hukum”, Alumni, Bandung, 1986.

Soedikno Mertokusumo I, "Hukum Dan Politik Agraria", KarunikaUniversitas Terbuka, Jakarta, 1988.

Soerodibroto Soenarto, "KUHP dan KUHAP", Raja Grafindo Persada, Jakarta, 1994.

Subekti, “Kamus Hukum”, PT. Pradanya Paramita, Jakarta, 2005.

Topo Santoso, “Kriminologi”, PT. Raja Grafindo Persada, Jakarta, 2001. 
Wantjik Saleh. K, "Hak Anda Atas Tanah", Ghalia Indonesia, Jakarta, 1985.

Departemen Pendidkan Nasional, "Kamus Besar Bahasa Indonesia”, Balai Pustaka. Jakarta, 2001. 
